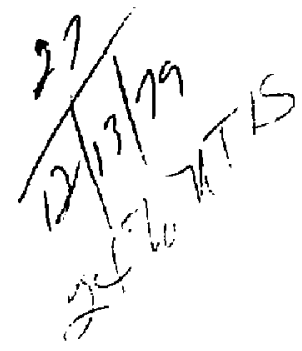

UCID- 18322

\title{
HYDROGEN RECYCLING IN TANDEM \\ MIRROR MACHINES
}

T. C. Simonen and R. P. Drake

November 14, 1979

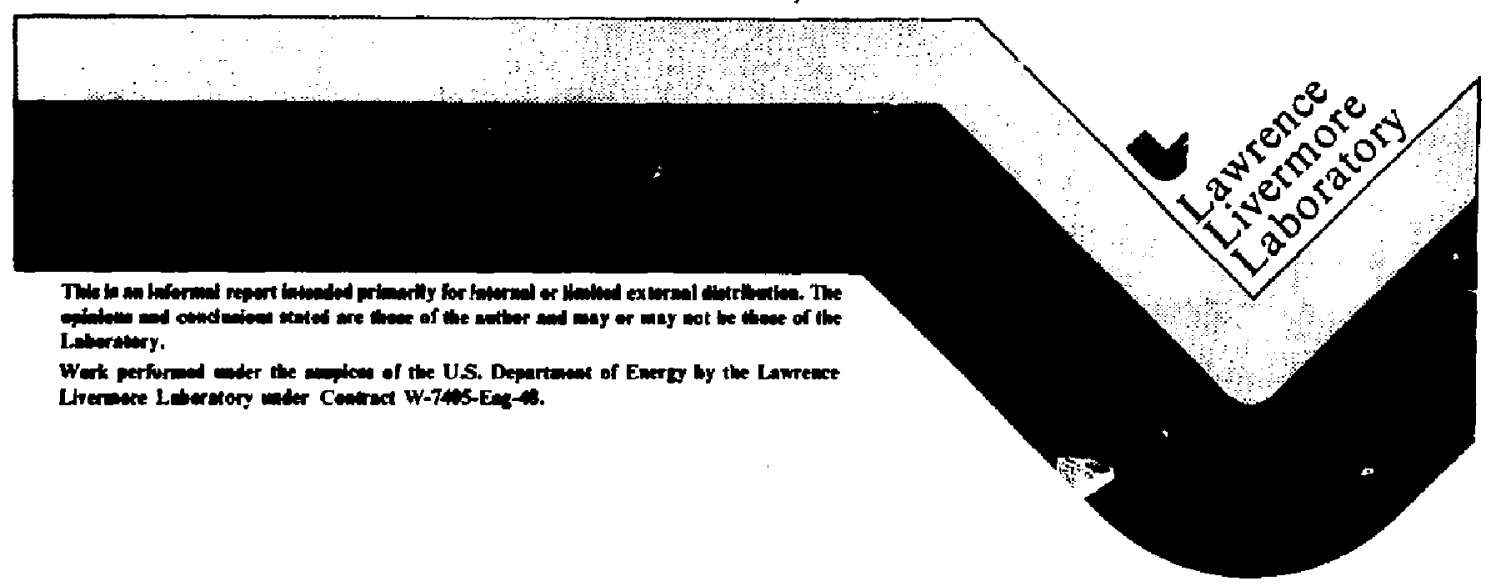

DISTRIBUTION OF TH:S ROCLEMEST IS UMLLGITED 


\section{INTRODHCTION}

This paper describes hydrogen recycling in tanden mirror machines. In $\mathrm{TMX}^{1}$ hydrogen (or deuterium) is introduced by the neutral beam injection system and by the solenoid gas feed system. Pumping is achieved by titanium gettering on liquid nitrogen panels. Mirror machine recycling differs from that in a tokamak. In mirrors, I I- sma losses are mainly to the large volume at the ends of the machine, remote from the hot plasma region. Similar techniques have been employed on 2 XIIB. $^{2}, 3$ The design of the TMX vacuum system was described by Atkinson. ${ }^{4}$ MFTF also employs an integral beam line vacuum system. However, since in MFTE the puise length is $0.5 \mathrm{sec}$, helium cayopanels are used to extend the pumping duration. Also special neutral beam and beam-ion dumps are employed.

\section{The TMX Vacuum System}

The sketch in Fig. 1 shows many Eearures of the TMK vac'un system. The system consists of two large stainless steel tanks which house the end plug magnets. These tanks are subdivided to pump gas from the $25 \mathrm{msec}$ duration neutral beam injectors. Most surfaces in this region are at liquid nitrogen temperature. The aluminum solenoid tank is at zoom temperature. All tanks are equipped with titanium getter wires ${ }^{5}$ which deposit a few monolayers of titanium per cycle throughout the machine. In total about 75 meters of 3 dia. getter wire is heated on each cycla.

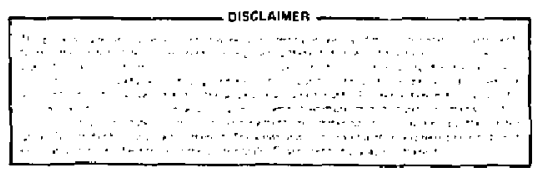




\section{TMX Vacuum System Measurements}

The end tanks of TMX must pump gas from the neutral beam injectors similar to a tokamak neutral beam line. Measurements of the pressure rise in various regions of ThX due to neutral beam gas has been carried out. Fig. 2 shows that the baffles between regions delays gas buildup into the plasma chamber and to the end far region. These measurements are without gettering and with the liquid-nitrogen liners warm. Fig, 2 shows that getterinf in the end fan region substantially reduces the pressure rise. Fig. 3 shows much further reduction in the pressure rise when the lincrs are cooled with liquid nitrogen. These measurements show that TMX plug vacuum system is performing qualitatively as designed. Detailed comparisons with ealeulations are in progress.

\section{Hydrogen Fueling of the TMX Solenoid}

Hydrogen is fed into the TX solenoid either by gas boxes or by a puffer valve. The gas boxes are located at the ends of the solenoid near the regions of high magnecic field where the plasma has a thin alliptical cross section. The puffer valve feeds hydrogen into the middle of the solenoid. The solenoid vacuum chamber radius is $42 \mathrm{~cm}$. The plasma $1 / \mathrm{e}$ density radius is 20 to $35 \mathrm{~cm}$.

An example of pressure rise in the solenoid without and with plasma is shown in Fig. 4. This case is an example of high gas feed rate with the puffer valve. We observe that plasma pumping reduces the ambient pressure. We find that if the gas valve is turned off during a shot, the plasma density rapidly decays indicating that the gas input controls the feed rather than wall recycling. 


\section{$\underline{\operatorname{Im} \alpha \text { Clean-UP }}$}

We have observed that it is necessary to getter both the end plug and center cell regions of TMX before we can get plasma buildup after initiai pumpdown. After gettering, we find that a few dozen shots with further gettering are required to extend the plasma duration to the ful1 $25 \mathrm{msec}$ neutral beam pulse. The extent to which gettering, as opposed to plasma-wall interactions, is important in this second scep has not been stud ied. 


\section{$-4-$}

\section{REFERENCES}

1. F. H. Coensgen, "TMX Major Project Proposal," LLL-Prop-148, Jan. 12, 1977.

2. T. C. Simonen, et al,, "Control of First-Wall Surface conditions in the 2 XIB Magnetic Mirtor Plasma Confinement Experiment," J. Nucl. Materials 63, 59 (1976).

3. B. W. Stallard, et al,, "plasma Wall. Charge Exchange Inceractions in the 2xItB Magnetic Mirror Experiment," UCRL-78741, presented at the International Symposium on Plasma wall Interaction, Oct. 18-22, 1976, Juelich, Germany.

4. D. P. Atkinson, M. O. Calderon and R. J. Nagel, "Vacuum System for the Tandem Mirror Experiment," UCRL-79750, Det. 4, 1977, paper presented at 7th Symposium of Fusion Rescarch, Knoxville, Tennessed, Oct. 25-28, 1977.

5. C. J. Andersau and V. A. Fintayson, J. Vac. Sci, Technol. I (1970). 
Figure 1

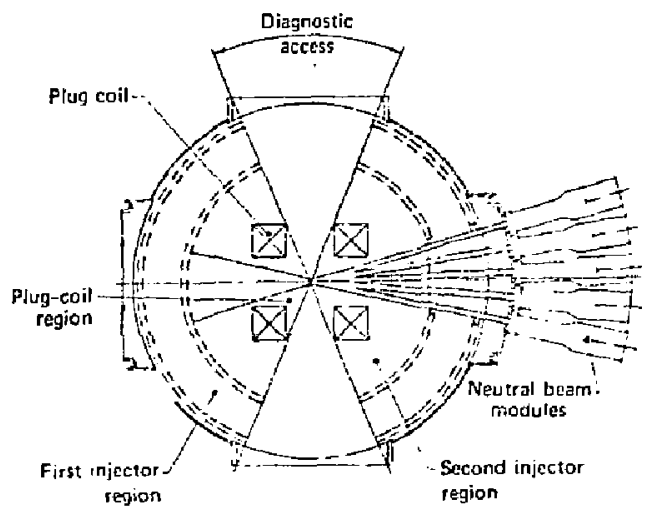

Cross seetion of the center of the plus tank.

Tat 10 1. Characteristies of TM pupping repions; areas ant volutes are giver on a per-plug susis.

\begin{tabular}{|c|c|c|c|}
\hline Regín & $\begin{array}{l}\text { Surface } \\
\text { cemperature, "C }\end{array}$ & $\begin{array}{l}\text { Surface } \\
\text { area, } m^{2}\end{array}$ & Volume, $\mathrm{m}^{3}$ \\
\hline First injector & -195 & 65.5 & 17.9 \\
\hline Second injuctor & -195 & 45.4 & 8.5 \\
\hline Plasma end dump & -195 & 33.8 & 14.8 \\
\hline Plus colt & 20 & 4.7 & 3.0 \\
\hline central cet 1 & 20 & 34.4 & 10.6 \\
\hline
\end{tabular}

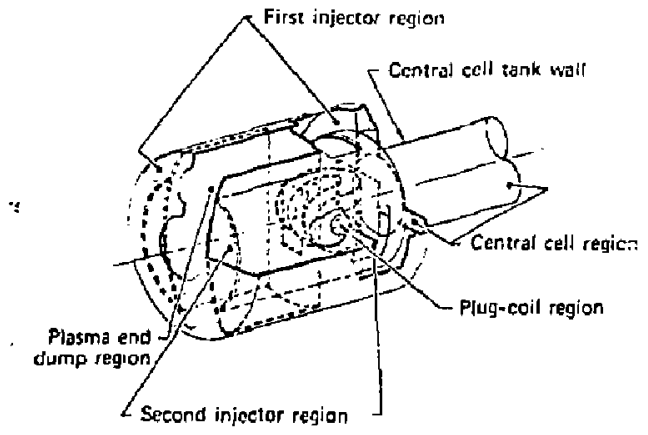

Dlapran of the THX Ineeral linars showing the pumplag rezions. 
Figure 2

PRESSURE RISE DUE TO A $60 \mathrm{~ms}$ GAS PULSE FROM ONE SOURCE

A. EFFECT OF BAFFLES

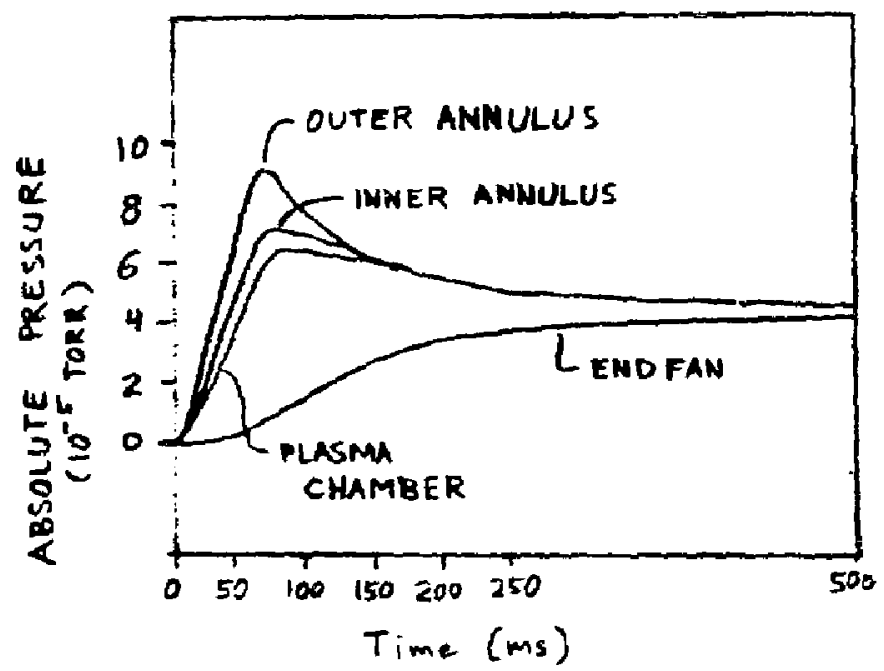

B. EFFECT OF BETTERING

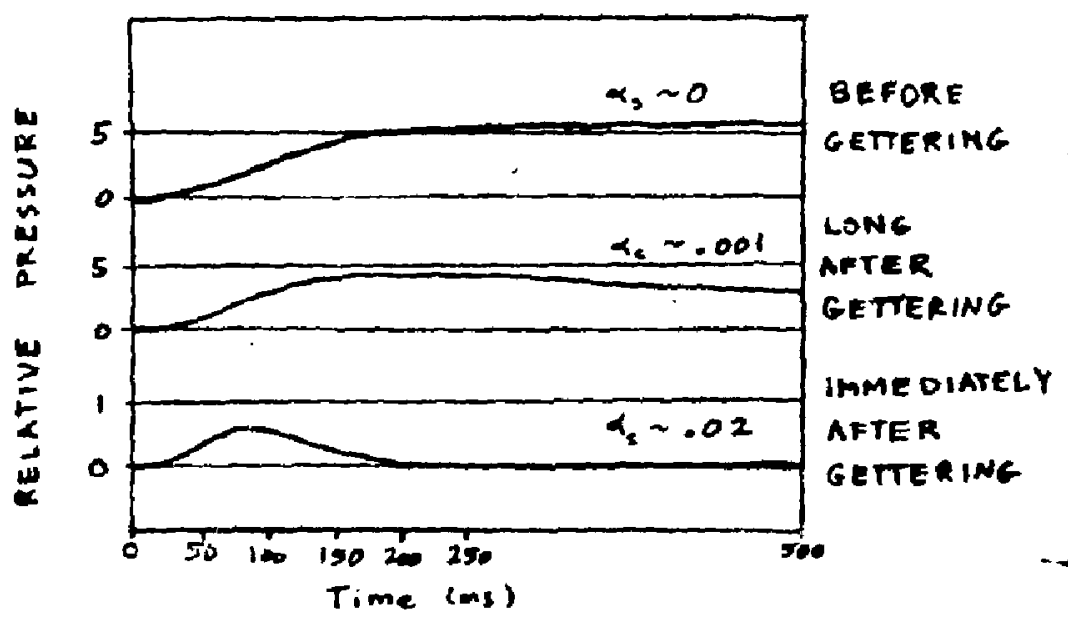


Figure 3

PRESSURE RISE AFTER GUTTERING DUE TO A $55 \mathrm{~ms}$ GAS PULSE FROM 8 BEAMS $\left(\sim 240\right.$ torr -l $\left.-5^{-1}\right)$.

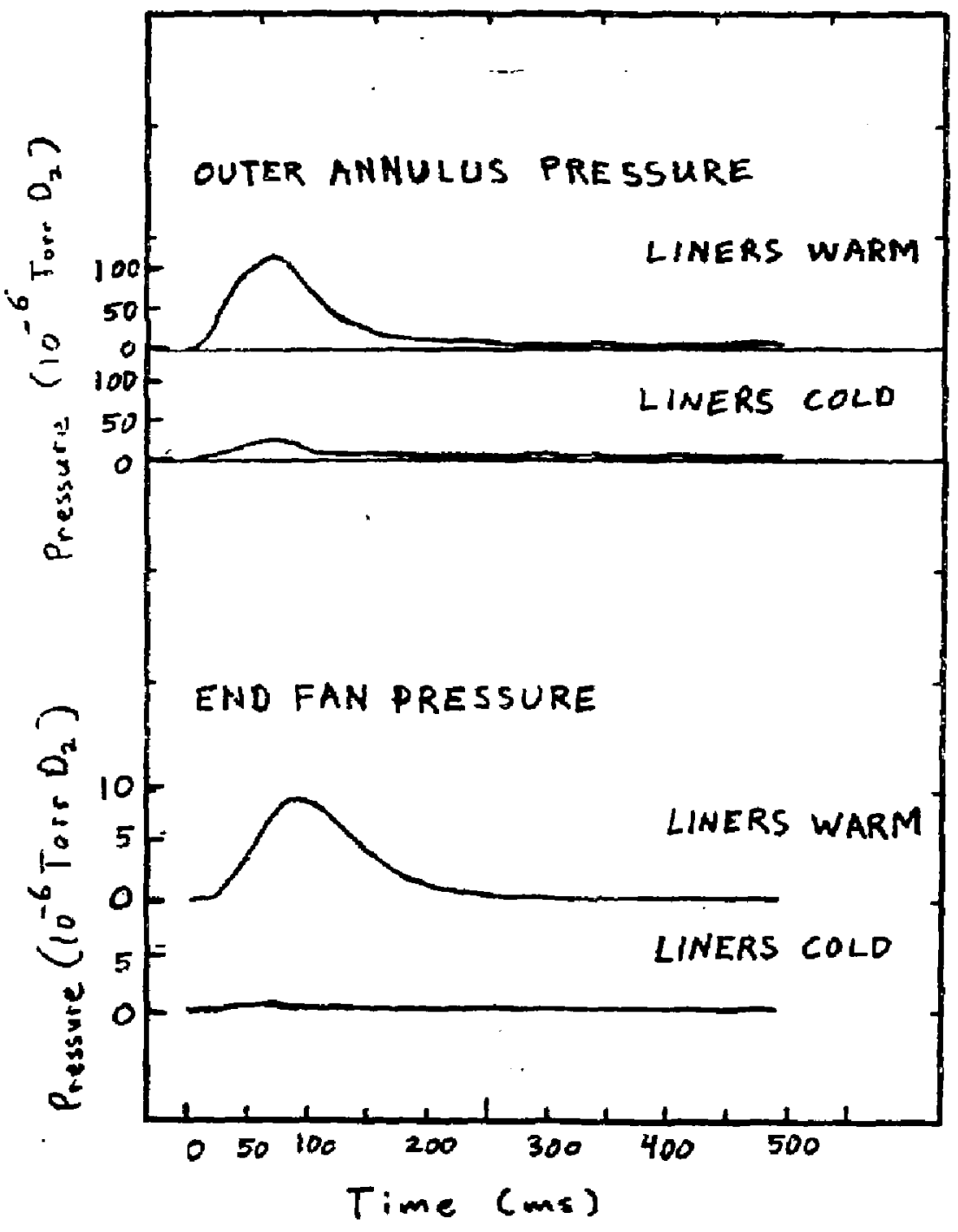

